\title{
可燃物配置の不規則性を考慮した実験にもとづく火災延焼モデル A FIRE SPREAD MODEL BASED ON EXPERIMENTS CONSIDERING RANDOM DISTRIBUTION OF COMBUSTIBLES
}

\author{
出口嘉一*1, 河野 守*2, 过本 誠*3, 五頭 辰 紀*4 \\ Yoshikazu DEGUCHI, Mamoru KOHNO, Makoto TSUJIMOTO \\ and Tatsuhiro GOTO
}

\begin{abstract}
Most fire risk analyses have been done only taking the density, i.e. the average amount per unit floor area, of combustibles into consideration. However, risk caused by a fire is anticipated to depend not only on the combustible density but also on other parameters of combustibles, such as shapes, distribution pattern and so on, especially at growth stage of the fire.

So, it is important to explain effects of combustible properties on heat release rate analyzed by fire spread model considering some fire physical models. The objective of this paper is to improve fire spread model based on wood crib fire experiments in which combustion properties of wood crib, flame height, flame temperature and requirements for fire spread were observed. Then comparing experiment results with analysis results using this model conformed the validity of this models.

Finally, result of analyses showed that the improvement model can evaluate quantitively fire spreading of wood crib with accuracy.
\end{abstract}

\section{Keywords: Combustibles characteristics, Fire load distribution, Combustible density, Fire spread model, Heat release rate} 可燃物特性, 可燃物配置, 可燃物密度, 火災延焼モデル, 発熱量

\section{1 はじめに}

避難安全性を検証する場合には，例えば建築基準法令に規定さ れる避難安全検証法において採用されているように，火災初期におう ける煙等降下時間は, 室に持ち込まれる可燃物総量の指標である可 燃物密度 (厳密には単位床面積あたりの発熱量)にもとついて決定 することが，少なくとも日本においては広く行われてきた．筆者ら は, 初期火災時において, 火災が出火源から他の可燃物への延焼 や内装への延焼などを経て拡大する過程で, 可燃物密度以外の出 火源近傍の可燃物特性 (配置, 大きさ, 燃焼性等) が煙等降下時間 に大きな影響を及ぼすことを明らかにした ${ }^{1)}$.さらに, 複数の火災 の物理現象を考慮した火災延焼モデル (以後 旧モデル) を構筑する ことで, 室発熱速度等の火災性状を時刻歴で計算し, 可燃物特性 が室発熱速度に及ぼす影響について報告した ${ }^{2)}$ 。しかし, 旧モデル では，個々の火災現象の物理モデルを複合して考慮してはいるもの の, それぞれの物理モデルの適応範囲が異なっていること等から， それらを統合して考えた場合に，適切に実現象を再現できるかは 不明確であった。
本報では，初期火災時における火災の拡大に影響を及ぼすと考 えられる可燃物特性の中から, 可燃物配置の影響に着目するため, 同程度の燃焼性状を有する同型のクリブを用いた延焼実験 ${ }^{3)}$ を行

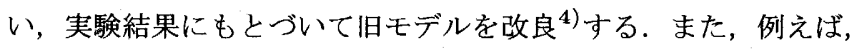
市街地火災での延焼において火炎による放射の影響をクリブ延焼実 験により算定している既往の研究5) に代表されるように, クリブを 規則正しく配置した状況を想定した実験は数多くなされているが, 可然物配置の不規則性に着目した実験はほとんど行われておらず, 複数のクリブを用いて, 不規則配置を含めた 4 通りの配置パター ンで火災延焼実験を行い, 実験結果と解析結果を比較することで, 改良した火災延焼モデル (以後 改良モデル) の妥当性を検証する.

\section{2 クリブ延焼実験}

\section{1 火災延焼モデルの概説と実験の考え方}

図 1 に示すように，旧モデルでは，可燃物の延焼は火炎および 天井部に溜まった高温の煙層からの放射の和を考え, 受熱側可燃物 の重心位置における (1) 式で示される放射の和が (2) 式で示され
*1 東京理科大学総合研究所

COEポストドクトラル研究員・博士 (工学)

2 国土技術政策総合研究所建貿研究部防火基準研究室 室長・工博

*3 東京理科大学総合研究所 教授. 工博

*4 国土技術政策総合研究所建築研究部防火基準研究室 主任研究官
Tokyo University of Science, Dr. Eng.

National Institute for Land and Infrastructure Management, Dr. Eng.

Prof., Tokyo University of Science, Dr. Eng.

National Institute for Land and Infrastructure Management 
る総受熱量の条件を満たすと着火すると仮定した．本報では, 2.3 に後述するクリブを用いた場合において，ある火源から他の火源へ の放射による延焼条件を明らかにするために，クリブの発熱速度， 着火温度および入射熱流束を測定項目として，実験結果をもとに， 単体で燃焼するクリブの燃焼性状，放射面高さ，放射面温度，入射 熱流束ならびに延焼条件に関するモデルの改良を行う。なお，旧モ デルでは，天井部に溜まった高温の煙層からの放射を考慮していた が，実験ではファンにより煙層が排気されるため，ここでは煙層か らの放射は考えないものとした．さらに，区画火災での壁等の影 響についても同様の理由から今回は考えないものとする.

$$
\begin{aligned}
I(t)= & I_{f}(t)+I_{s}(t) \\
= & \sum_{i=1}^{n} I_{i}(t)+I_{s}(t) \\
= & \sum_{i=1}^{n} \sigma \epsilon_{f} \varphi_{i}\left(T_{f}^{4}-T_{0}^{4}\right)+\sigma \epsilon_{s} \varphi_{s}\left(T_{s}(t)^{4}-T_{0}^{4}\right) \\
& \int_{0}^{t_{i g}} I^{2}(t) d t=120,000
\end{aligned}
$$

$$
\text { ここで, }
$$

$I(t) \quad: \quad$ 時間 $t$ での受熱放射量の和 $\left(\mathrm{kW} / \mathrm{m}^{2}\right)$

$I_{f}(t) \quad: \quad$ 時間 $t$ での火炎からの放射量の和 $\left(\mathrm{kW} / \mathrm{m}^{2}\right)$

$I_{s}(t) \quad$ ：時間 $t$ での煙層からの放射量 $\left(\mathrm{kW} / \mathrm{m}^{2}\right)$

$I_{i}(t)$ : 時間 $t$ での火炎 $i$ からの放射量 $\left(\mathrm{kW} / \mathrm{m}^{2}\right)$

$\sigma$ : Stefan-Boltzmann 定数 $\left(5.67 \times 10^{-11} \mathrm{~kW} / \mathrm{m}^{2} \mathrm{~K}^{4}\right)$

$\epsilon_{f}:$ 火炎の放射率 (1.0)

$\epsilon_{s} \quad$ ： 煙層の放射率 (1.0)

$\varphi_{i} \quad$ ： 火炎 $i$ の受熱面に対する形態係数

$\varphi_{s} \quad$ ：煙層の受熱面に対する形態係数

$T_{f}$ : 放射面 (火炎面) 温度 $(1073 \mathrm{~K})$

$T_{0} \quad$ ： 受熱面の初期温度 $(293 \mathrm{~K})$

$T_{s}(t) \quad$ : 時間 $t$ での煙層温度 $(\mathrm{K})$

$t_{i g} \quad$ ：着火時間 (s)

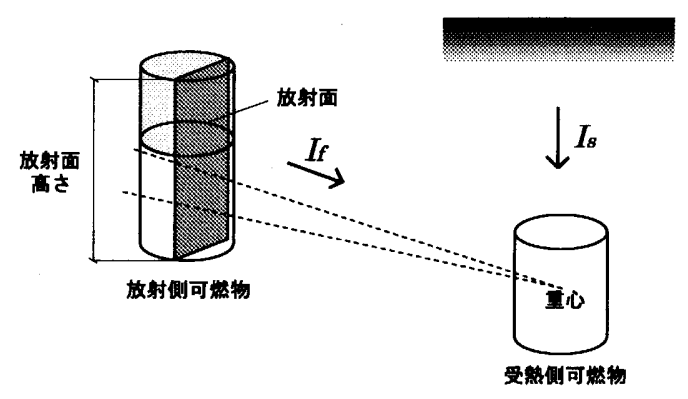

図 1 火災延焼モデルでの熱伝達

\section{2 実験概要}

独立行政法人建築研究所内のルームコーナ一試験装置 (ISO9705) の集煙フードを用いて，酸素消費法により発熱速度の計測を行っ た. 集煙フード下部寸法は $3 \mathrm{~m}$ 角, 排気ダクト直径は $0.6 \mathrm{~m}$ であ る. 排気ファンは, 酸素消費法による発熱速度の測定が適切に行え るように設定 (最大風量 $150 \mathrm{~m}^{3} / \mathrm{min}$ ) した. 図 2 に実験装置の概 略を示す。

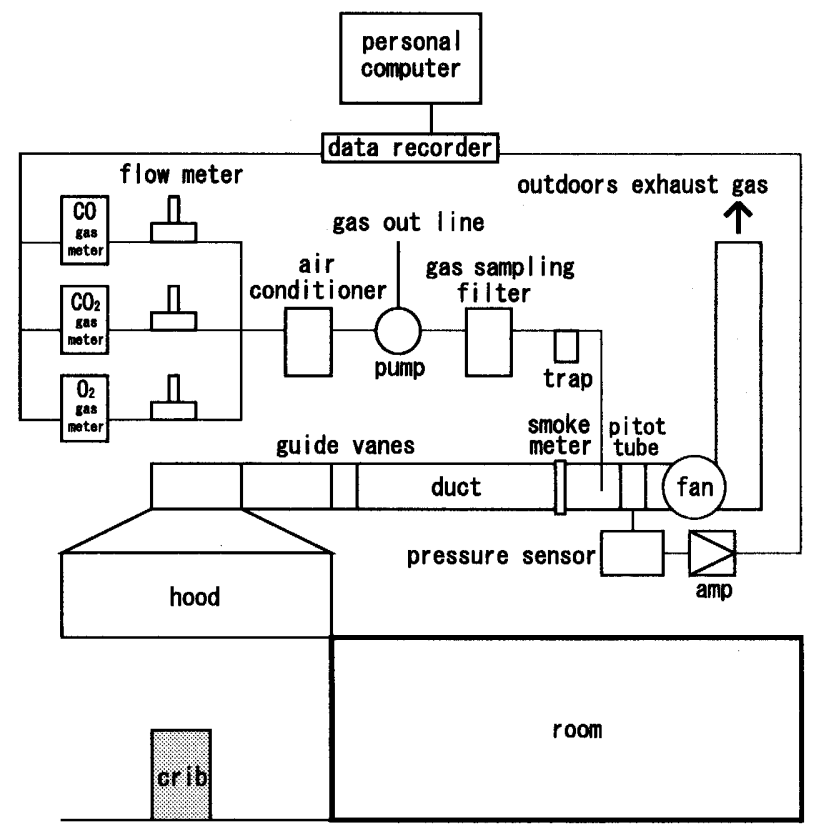

図 2 実験装置の概略

\section{3 クリブの概要}

本実験では，標淮的な大きさの可燃物を想定した図 3 に示すク リブを使用した。 クリブを構成する木材には， $200 \times 30 \times 30 \mathrm{~mm}$ の赤松を使用し, 乾燥機にて 48 時間乾燥後, 室温約 $25{ }^{\circ} \mathrm{C}$ で数日 間養生した. なお，養生室内の湿度を調整することができなかった ため, 養生室内は約 $80 \%$ と高い湿度であった. クリブは, 1 層 4 本，12 層重ねたものを，木材 1 本あたり 2 本の釘を用いて井桁状 に組んだ．クリブ 1 個あたりの重量は約 $5 \mathrm{~kg}$ である. また, 出火 クリブから他のクリブへの延焼条件が安定するように, クリブが延 焼すると考えられる面に，木材よりも着火条件が安定しているイ ンシュレーションボードを格子状に組んだものを張り付けた (図 4 に太線で示す). なお, 実験で使用したインシュレーションボード (密度 : $0.3 \mathrm{~g} / \mathrm{cm}^{3}$, 厚さ : $9 \mathrm{~mm}$ ) は, クリブを構成する木材と同 様の条件で養生した。
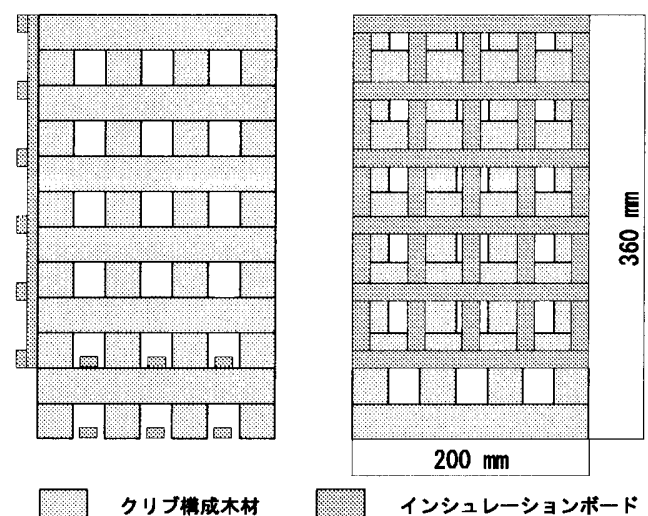

図 3 クリブの概要

\section{4 測定方法}

本報では，主にクリブ間の延焼条件を決定するために行った予 備実験にもとづいて火災延焼モデルの改良を行い，9個のクリブの 配置を変更した 4 通りの実験 (実験(1)〜(4)) 結果と改良モデルによ 
る解析結果を比較することで改良モデルの妥当性を検証する．な お， 実験(1)，標準モデルとして 9 個のクリブを $3 \times 3$ に規則的 に並べた. 実験(2)は，標準モデルのクリブ間距離 $d$ を変更したも のである．実験(3)および実験(4)は，異なるクリブ間距離をとる不規 則性を考慮した配置とした. 表 1 にクリブ配置の概要を, 表 2 に 各実験でのクリブおよびインシュレーションボードの重量を示す. すべての実験において，配置図に示す中央 (1 番) のクリブを着火 点とし，図 3 に示すクリブの 1 段目と 3 段目にメタノール約 100 $\mathrm{g}$ を含浸させたインシュレーションボード $(200 \times 15 \times 9 \mathrm{~mm})$ を挿 入し, 点火した. なお, 改良モデルでは着火したクリブは瞬時に クリブ全体が燃焼するため, 出火クリブ (1 番) 以外のクリブにも, 着火したクリブの燃焼を促進させるために， 3 段目と 5 段目にイ ンシュレーションボード (内部 I.B.) を挿入した.

表 1 クリブ配置の概要

\begin{tabular}{cccc}
\hline 実験番号 & 個数 & $d(\mathrm{~m})$ & 備考 \\
\hline \hline 予備実験 & 3 & $0.2,0.3$ & 予備実験 \\
\hline (1) & 9 & 0.2 & 標淮モデル \\
\hline (2) & 9 & 0.1 & \\
\hline (3) & 9 & $0.1 \sim 0.2$ & 不規則配置 \\
\hline (4) & 9 & $0 \sim 0.3$ & 不規則配置 \\
\hline
\end{tabular}

\section{表 2 実験の詳細}

\begin{tabular}{cccc}
\hline 実験番号 & $\begin{array}{c}\text { クリブ平均重量 } \\
(\mathrm{kg})\end{array}$ & $\begin{array}{c}\text { 表面 I.B. 重量 } \\
(\mathrm{kg})\end{array}$ & $\begin{array}{c}\text { 内部 I.B. 重量 } \\
(\mathrm{kg})\end{array}$ \\
\hline \hline 予備実験 & $4.86(4.81-5.04)$ & 0.25 & 0.14 \\
\hline (1) & $5.00(4.85-5.24)$ & 1.47 & 0.41 \\
\hline (2) & $4.96(4.79-5.09)$ & 1.43 & 0.49 \\
\hline (3) & $5.10(4.74-5.47)$ & 1.49 & 0.42 \\
\hline (4) & $4.99(4.89-5.31)$ & 1.19 & 0.41 \\
\hline
\end{tabular}

\section{3 モデルの改良}

\section{1 可燃物の燃焼性状}

旧モデルでは, 可燃物を円筒形の木材と仮定し, 発熱速度 $Q(t)$ は (3)(4) 式で示される $\alpha-t^{2}$ モデルで仮定していた.

$$
Q(t)= \begin{cases}0.0125 \cdot t^{2} & t \leq t_{p} \\ Q_{p e a k} & t_{p}<t \leq t_{d}\end{cases}
$$

$$
Q_{p e a k}=q_{s} \times A
$$

ここで,

$Q(t) \quad$ ： 時間 $t$ での可燃物の発熱速度 $(\mathrm{kW})$

$Q_{\text {peak }}$ ： 可燃物の発熱速度の最大值 $(\mathrm{kW})$

$q_{s} \quad$ : 木材の単位表面積あたりの発熱速度 $\left(112 \mathrm{~kW} / \mathrm{m}^{2}\right)$

$A$ ：可燃物の底面を除く表面積 $\left(\mathrm{m}^{2}\right)$

$t_{p} \quad$ : 最大発熱速度に至る時間 $(\mathrm{s})$

$t_{d} \quad$ ：可燃物の鎮火時間 (s)

図 5 は, 予備実験での単体クリブの発熱速度, 直径 $0.2 \mathrm{~m}$, 高 さ $0.36 \mathrm{~m}$ の円筒を仮定した旧モデルおよび改良モデルでの単体 クリブの発熱速度を示したものである. 実験で使用したクリブは, 木材を井析状に組んでいるため, 旧モデルで仮定した可燃物の表面 積よりも実際の表面積が大きくなり，最大発熱速度も大きくなる. そこで, 改良モデルでは，(5)(6) 式で示されるように，実験結果 をもとに着火から 17 分間は発熱速度が時間比例で上昇し, その後 6 分間, 旧モデルの最大発熱速度を 2.7 倍した值で定常燃焼を継続 し， 23 分後に鎮火するモデルを仮定する．これにより，実際より も燃焼継続時間は短くなるが，総発熱量はほぼ同じである．なお， 旧モデルでは燃焼に応じて可燃物の高さが減少するモデルを仮定 していたが，実験ではクリブは形状を維持したまま燃焼を続け，約 35 分後に突燃崩れ落ちる傾向があったため, 以後, 改良モデルに おいて高さの減少は考慮しないものとする。

$$
\begin{gathered}
Q(t)= \begin{cases}\frac{Q_{\text {peak }}}{1020} \cdot t & t \leq 1020(s) \\
Q_{\text {peak }} & 1020<t \leq 1380(s)\end{cases} \\
Q_{\text {peak }}=2.7 q_{s} \times A
\end{gathered}
$$

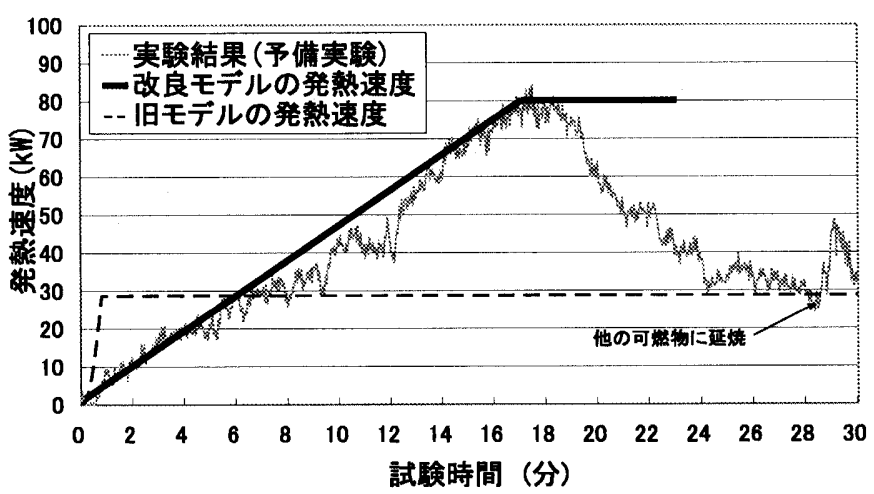

図 5 クリブの燃焼性状のモデル化

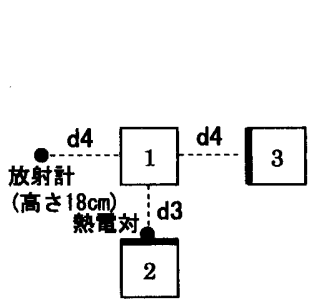

予菕実験
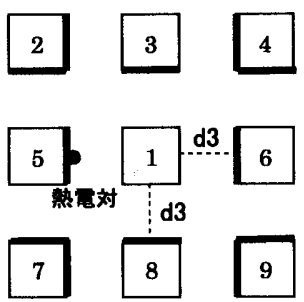

実験(1)

$d 1=0.1 m$ d2 $=0.15 m$ d3 $=0.2 m$ d4 $=0.25 m$ d5 $=0.3 m$

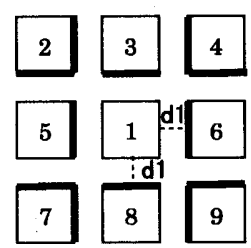

実験(2)

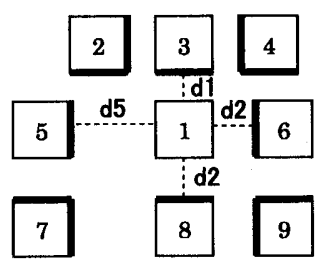

実験(3)

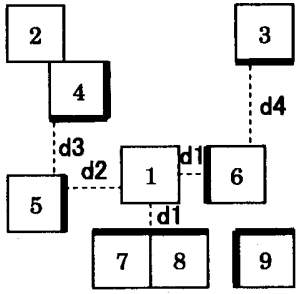

実験(4)

図 4 実験でのクリブ配置 


\section{2 放射面高さ (火炎高さ)}

図 1 に示すように，旧モデルにおいて，円筒形の可燃物上部に 円筒形の火炎が形成され, 受熱側可燃物の重心位置から放熱側可燃 物への接線により切り取られる面を放射面と仮定した。このとき, 放射面高さは, Zukoski の間歇火炎高さを求める式 ${ }^{6)}$ の半分の高さ を仮定している $((7)$ 式). 図 6 に, 直径 $0.2 \mathrm{~m}$, 高さ $0.36 \mathrm{~m}$ の 円筒を旧モデルおよび改良モデルに従って計算した放射面高さお よび火炎高さの時間変化を示す目安として日本アビオニクス㮫製 サーモグラフィ※(TVS-100(検出波長 3-5.4 $\mu \mathrm{m}$ )) で $200{ }^{\circ} \mathrm{C}$ を示 す最高高さを示す. ビデオ画像から判断して, 火炎高さは時間的に 伸縮することを考虑すると放射面高さとして (7) 式の仮定は妥当 な範囲であった，なお，火㷋延焼モデルにおいて，放射面高さはク リブ上部に形成される火炎にクリブ本体の高さを加えた值とした.

$$
\begin{aligned}
& \frac{L_{\text {min }}}{D}= \begin{cases}1.65 \cdot Q^{* \frac{2}{3}} & Q^{*}<1 \\
1.65 \cdot Q^{* \frac{2}{5}} & Q^{*} \geq 1\end{cases} \\
& Q^{*}=\frac{Q}{\rho_{0} C_{p} T_{0} \sqrt{g} D^{\frac{5}{2}}} \\
& \text { ここで, } L_{\text {min }} \text { ： 放射面高さ }(\mathrm{m}) \\
& Q^{*} \quad \text { : 無次元発熱速度 } \\
& Q \text { ： 火源の発熱速度 }(\mathrm{kW}) \\
& \rho_{0} \quad \text { : 大気の密度 }\left(1.2 \mathrm{~kg} / \mathrm{m}^{3}\right) \\
& C_{p} \text { ：空気の定圧比熱 }(1.0 \mathrm{~kJ} / \mathrm{kgK}) \\
& T_{0} \quad \text { ：常温空気の絶対温度 }(293 \mathrm{~K}) \\
& g: \text { 重力加速度 }\left(9.8 \mathrm{~m} / \mathrm{s}^{2}\right)
\end{aligned}
$$

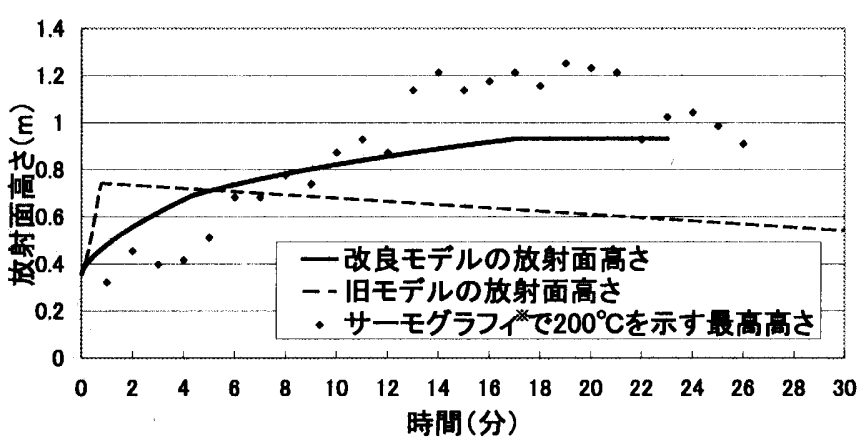

図 6 放射面高さの時間変化

\section{3 放射面温度}

旧モデルでは, 発熱速度 $Q$ のうち 7 割がプルームを介して煙層 温度の上昇に寄与するものとし, かつ, 放射面温度は発熱速度と は無関係に $800{ }^{\circ} \mathrm{C} に$ 固定していた。このことが原因で, 実際の可 燃物の発熱速度以上の放射エネルギーを放出している場合があり， 発熱速度に対応した放射面温度モデルを仮定する必要があった，そ こで, 発熱速度 $Q$ の 3 割が放射に寄与するものとして, 底面を除 く円筒形の放射面から均等に放射があるものとし，(9) 式で放射量 $I_{f}(t)$ を仮定した. 図 7 に，旧モデルおよび改良モデルによる放射 面温度の時間変化を示す。

$$
\begin{gathered}
I_{f}(t)=\frac{0.3 Q(t)}{A_{f}} \\
A_{f}=\pi\left(\frac{D}{2}\right)^{2}+\pi D h \\
T_{f}(t)=\left(\frac{I_{f}(t)}{\sigma \epsilon_{f}}+T_{0}^{4}\right)^{1 / 4}
\end{gathered}
$$
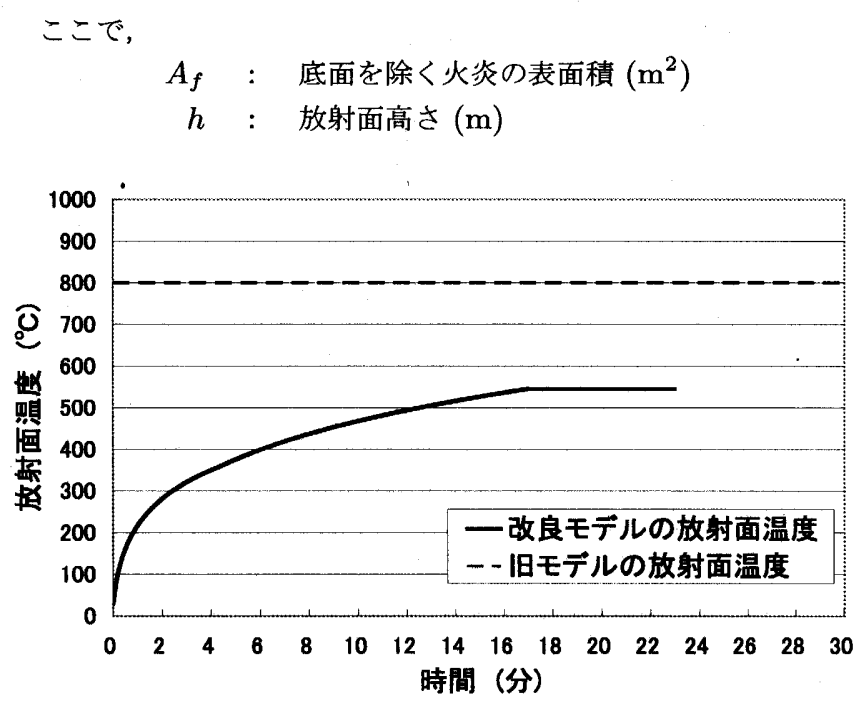

図 7 放射面温度の時間変化

\section{4 入射熱流束}

図 8 に予備実験で測定した入射熱流束 (図 4) の実測值, 同様の 条件を仮定した旧モデルおよび改良モデルに従って計算した入射 熱流束の計算值をあわせて示す．ただし，計算值ではクリブに内接 する円筒を仮定している分, 放射面が小さくなるため, 実測值と比 較して入射熱流束の值が小さくなる，なお，実験で入射熱流束は， Schmidt-Boelter 型熱流束計 $(\phi=15 \mathrm{~mm})$ を用いて測定した.

図 5 に示すように，実験でのクリブの発熱速度は，着火から約 17 分後に最大值を示した後, 徐々に減少する. しかし, 図 8 に示 す実験での入射熱流束の測定值は，クリブの発熱速度が最大值を 示した後も上昇し，その後も減少することなく定常状態を示して いる.これは，クリブの燃焼形態が時間の経過とともに変化する ことが原因であると考えられる.つまり，発熱速度が最大值を示す あたりまでは，炎を形成し勢いよく酸素を消費している(発熱速度 が大きい)のに対して，時間の経過とともにクリブが炭化し，消費 酸素は少ない (発熱速度は小さい)ものの入射熱流束は大きな燃焼 へと移り変わる.このような理由から，改良モデルでクリブの発 熱速度を図 5 に示すように最大值を示した後，定常状態に移行す るモデルとした．また，旧モデルでは放射面温度を着火直後から $800{ }^{\circ} \mathrm{C}$ で固定していたため，入射熱流束も実測值と比較してかな り大きな值となっていた．しかし，改良モデルではこの点は改良さ れておう，入射熱流束の時間変化を比較的よく表している.

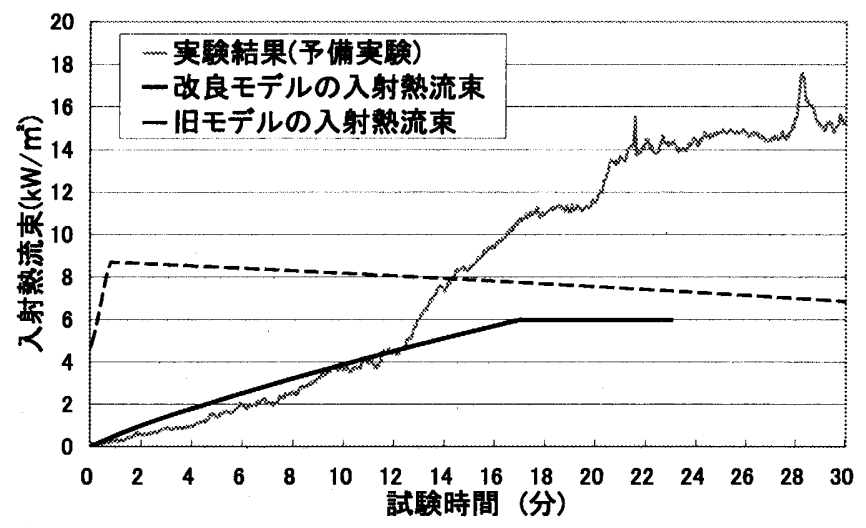

図 8 実験および解析の入射熱流束の時間変化 


\section{5 可燃物の延焼条件}

図 9 に，K型熱電対 (クロメルーアルメル $\phi=0.1 \mathrm{~mm}$ )により 測定した予備実験および実験(1)でのクリブの延焼面 (熱電対を張り 付けた位置は図 4 参照) に張り付けたインシュレーションボードの 表面温度変化を示す. 両実験において, インシュレーションボード の表面温が約 $300{ }^{\circ} \mathrm{C}$ 至ると急激に温度が上昇していることやビ デオ映像等から判断すると, インシュレーションボードは約 300 ${ }^{\circ} \mathrm{C}$ で安定して着火すると考えられる.

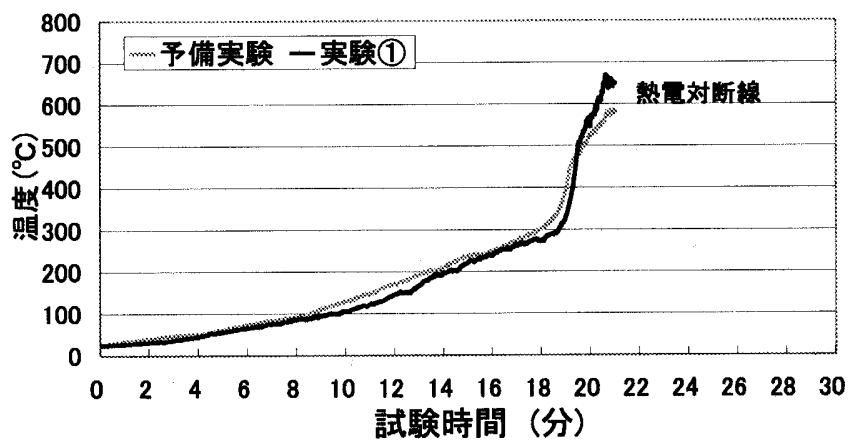

図 9 インシュレーションボード表面温 (予備実験および実験(1)

図 10 に着火性試験 (ISO5657)にもとづく数種類の木材 ${ }^{7)}$ とイン シュレーションボードの着火時間と放射の関係をあわせて示す. 図 中のインシュレーションボードの着火時間と放射の関係から，(12) 式 (図中：実線) が導かれる. しかし，この条件式を用いた解析結 果は, 図 11〜14に後述するように, 実験結果よりも比較的早く延 焼が桩大する。この原因の 1 つに，例えば木材は限界入射熱 $(15$ $\left.\mathrm{kW} / \mathrm{m}^{2}\right)^{8)}$ 以下の放射では, 表面が炭化するのみで着火しないと いわれており，インシュレーションボードについても同様の現象が 確認されたことが挙げられる.また, 着火性試験では, 試験体は試 験開始から一定の放射強度で一様に加熱されていることや，イン シュレーションボードの限界入射熱が明らかでないことから，ここ では簡単に着火条件を (13) 式 (図中：点線) で仮定する.

$$
\begin{aligned}
& \int_{0}^{t_{i g}} I_{f}^{2}(t) d t=120,000 \\
& \int_{0}^{t_{i g}} I_{f}^{2}(t) d t=30,000
\end{aligned}
$$

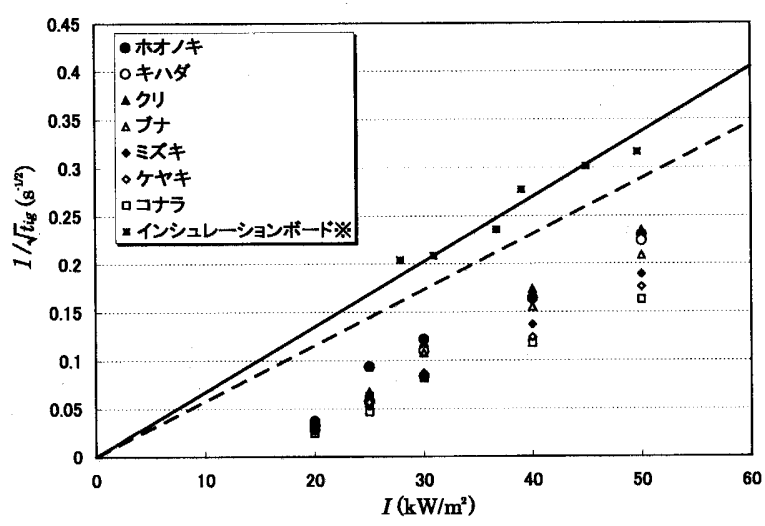

図 10 インシュレーションボードおよび木材の着火時閒と放射量の関係7) ※インシュレーションボードのデータは吉田正志氏 (建築研究所) の提供による

\section{6 旧モデルの改良点のまとめ}

3.1 燃焼性状

図 5 に示す予備実験での単体クリブの発熱速度をもとに，可 燃物の燃焼性状を仮定した.

$$
\begin{array}{ll}
\text { 旧モデル } & : \quad \alpha-t^{2} \text { モデル } \\
\text { 改良モデル } & : \quad \alpha-t \text { モデル }
\end{array}
$$

\section{2 放射面高さ}

然焼にともなう燃え落ちを除けば，旧モデルからの改良は 行っていない (図 6).

$$
\begin{array}{lll}
\text { 旧モデル } & \text { ： } & \text { 発熱速度に応じて変化 } \\
\text { 改良モデル } & : & \text { 発熱速度に応じて変化 }
\end{array}
$$

\section{3 放射面温度}

旧モデルでは $800{ }^{\circ} \mathrm{C} に$ 固定していた放射面温度を，改良モデ ルでは発熱速度に応じて変化するモデルに改良した (図 7).

$$
\begin{aligned}
& \text { 旧モデル ： } 800{ }^{\circ} \mathrm{C} \text { で一定 } \\
& \text { 改良モデル： 発熱速度に応じて変化 }
\end{aligned}
$$

\section{4 入射熱流束}

入射熱流束の計算式は改良していないが，放射面温度の計算 式が改良されたことにより，結果的に入射熱流束もより実測 値に近い値になるよう改良された (図 8).

$$
\begin{array}{lll}
\text { 旧モデル } & \text { ：発熱速度に依存しない } \\
\text { 改良モデル } & \text { ：発熱速度に応じて変化 }
\end{array}
$$

\section{5 延焼条件}

ISO 着火性試験結果をもとに，(2) 式で仮定していた着火判 定条件を (13) 式に改良した。

$$
\begin{array}{lll}
\text { 旧モデル } & : & \int_{0}^{t_{i g}} I_{f}^{2}(t) d t=120,000 \\
\text { 改良モデル } & : & \int_{0}^{t_{i g}} I_{f}^{2}(t) d t=30,000
\end{array}
$$

\section{4 ケーススタディによる実験結果との比較}

ここでは，実験(1)〜(4)をケーススタディとして改良モデルの妥 当性を検証する. 個々のクリブの大きさは, 実験で使用したクリブ に準じるように直径 $0.2 \mathrm{~m}$, 高さ $0.36 \mathrm{~m}$ の円筒形とする. 図 11 〜14 は改良モデルによる解析結果および実験結果の発熱速度の時 間変化をそれぞれ示したものである，旧モデルを用いて同様の解 析を行ったところ, 出火クリブから他のクリブに延焼することなく 燃え尽きるのに対して，改良モデルは，実験結果とよく一致して いる. なお， 図 11〜14 中の番号は, 延焼したクリブを順に示した ものである

標準モデルとした実験(1)は，実験結果と解析結果で各クリブへ の延焼時間も比較的よく一致していることがわかる. 一方，実験(2) のようにクリブ間距離が全体的に短い場合は, 合流火炎等の影響9) で燃焼が促進されたため, 改良モデルによる解析結果が実験結果よ りも緩やかに延焼している．また，実験(3)や実験(4)のように数種類 のクリブ間距離が混在している不規則な配置をとる場合において も解析結果と実験結果は比較的良く一致している，このように，合 流火炎は延焼条件に大きな影響を及ぼす現象の 1 つであることか ら，今後の検討課題としたい，また，すべての解析結果において， 単体クリブの発熱性状を最大発熱速度の継続時間を実際よりも長く 仮定したため，全体的に延焼から鎮火への経過が早くなっている. 


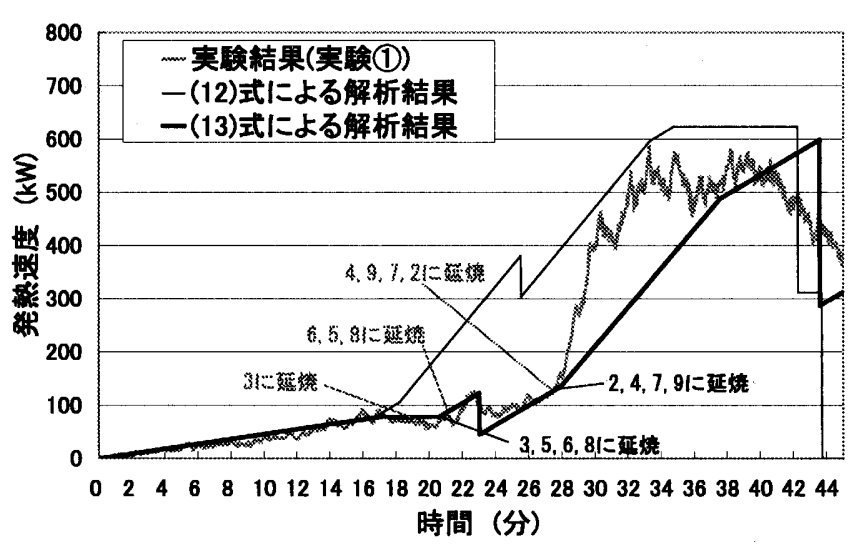

図 11 発熱速度の時間変化 (実験(1)

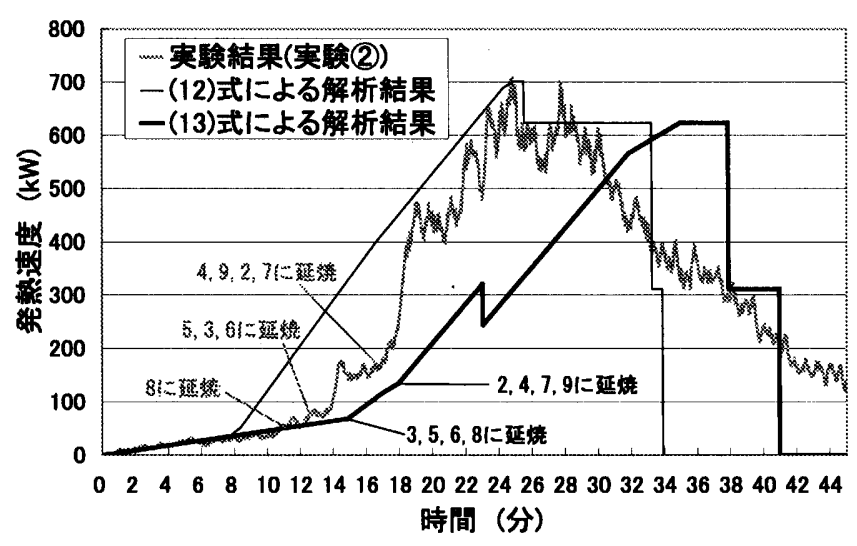

図 12 発熱速度の時間変化 $($ 実験(2)

\section{5 まとめと今後の課題}

本報では，クリブの延焼実験を行い，実験結果をもとに火災延 焼モデルの改良を行った．また，ケーススタディとして，9個のク リブを使用した延焼実験と同条件での改良モデルによる解析を行 い，実験結果と解析結果を比較することで，以下の知見を得た.

・放射面温度を発熱速度に応じて変化するモデルとすることで, 入射熱流束の計算值が実験値に比較的よく対応する

・クリブ間距離が短い場合，合流火炎等の影響で延焼が促進さ れるため, 改良モデルによる計算值は実験值よりも延焼が緩 やかとなる

本報では，可燃物として木材クリブを使用したが，同様の手順 を踏むことにより，木材以外にもプラスティック等の燃焼性状の異 なる可燃物を考慮した火災延焼モデルの構築も可能である．また， 今回は比較的小さく，同じ大きさのクリブを複数個使用した実験を 行ったため, 可燃物の大きさが延焼に及ぼす影響については考虑さ れていない，火災延焼モデルでは，受熱側クリブの重心位置で，入 射熱流束を計算するため, 可燃物が大きくなるにつれて, 可燃物表 面間距離との差が大きくなってしまう. 今後は，このような木材以 外の可燃物のモデル化，クリブの大きさが延焼に及ぼす影響を明ら かにするとともに，出火源近傍の可燃物特性のデータの蓄積および 合流火炎等の影響を考慮したモデルのさらなる改良が必要である.

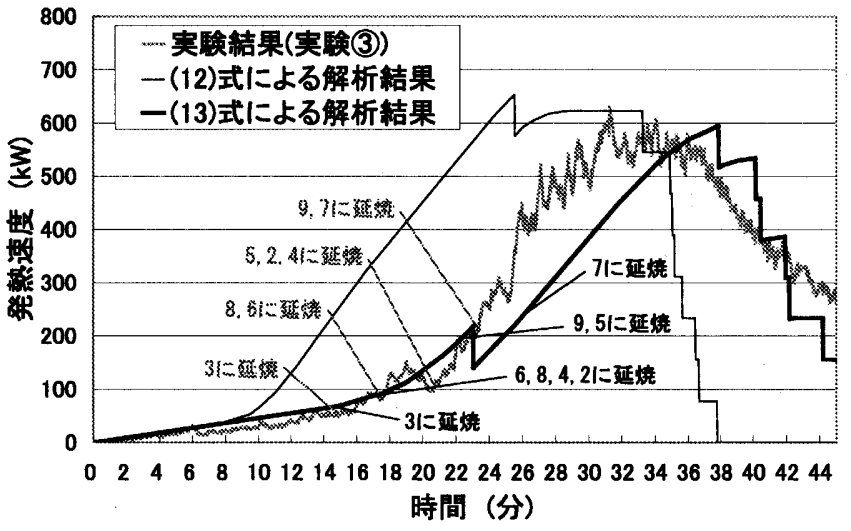

図 13 発熱速度の時間変化 (実験(3))

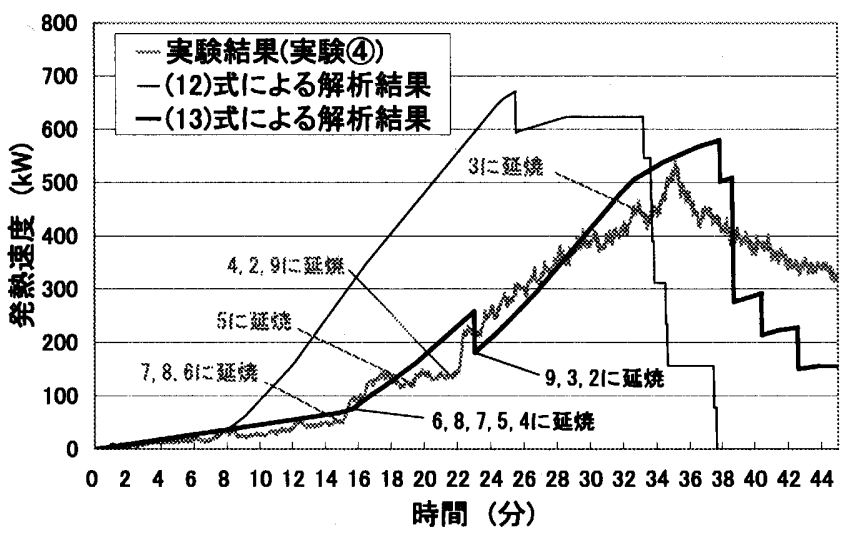

図 14 発熱速度の時間変化 (実験(4))

謝辞

本研究は, 筆頭筆者が建築研究所非常勤研究員在籍時に実施し た実験を中心にまとめたものである. また, 実験遂行にあたり，吉 田正志氏 (独立行政法人建築研究所) のご協力を頂きました。ここ に記して，謝意を表します。

参考文献

1) 出口嘉一, 辻本誠, 河野守 : 可燃物のランダム配置による発熱量と煙流動の 影響に関する研究，日本建築学会計画系論文集，No.565, pp.1-7, 2003.3

2) 出口嘉一, 辻本誠, 河野守: 可燃物の分布特性が火炎初期発熱性状に及ぼす 影響, 日本建築学会環境系論文集, No.580, pp.9-14, 2004.6

3）出口嘉一, 河野守, 五頭辰紀, 辻本誠 : 火災燃焼モデルの構筑を目的とする クリブ燃焼実検, 日本火災学会研究発表会概要集, pp.104-107, 2004.5

4) 出口嘉一, 河野守, 辻本誠: クリブ燃焼実験にもとづく火災延焼モデルの改 良，日本建築学会大会概要集，pp.363-364，2004.8

5）村岡宏，森脇哲男，飯島道夫，西田幸夫，江田敏男：市街地火災に関する実 験的研究 (その 3) -クリブの輻射受熱量に関する検討一, 日本建築学会学 術講演梗概集, pp.1067-1068, 1990.10

6) Zukoski, E.E.:Fluid Dynamic Aspects of Room Fires, Fire Safety Science-Proceedings of the First International Symposium, pp.130, 1986

7）長谷見雄二, 吉田正志 : 材料表面の着火性予測評価手法, 日本建築学会学術 講演梗概集 (防火部門), pp.809-810, 1987.10

8）田中哮義, 建築火災安全工学入門, 日本建築センター, p.227, 1993

9）鍵屋浩二, 長谷見雄二，福田達郎，伊藤重人：自由空間の複数火源による火 炎高さの定量実験, 日本火災学会研究発表会概要集, pp.428-431，2002.5 